\title{
HIF-1 $\alpha$ acts as a molecular target for simvastatin cytotoxicity in B16.F10 melanoma cells cultured under chemically induced hypoxia
}

\author{
EMILIA LICARETE ${ }^{1,2}$, ALINA SESARMAN ${ }^{1,2}$, VALENTIN FLORIAN RAUCA ${ }^{1}$, \\ LAVINIA LUPUT $^{2}$, LAURA PATRAS ${ }^{1,2}$ and MANUELA BANCIU ${ }^{1,2}$ \\ ${ }^{1}$ Department of Molecular Biology and Biotechnology, Faculty of Biology and Geology, \\ Babes-Bolyai University; ${ }^{2}$ Molecular Biology Centre, Institute for Interdisciplinary Research \\ in Bio-Nano-Sciences, Babes-Bolyai University, 400006 Cluj-Napoca, Romania
}

Received September 23, 2016; Accepted January 31, 2017

DOI: $10.3892 / \mathrm{ol} .2017 .5928$

\begin{abstract}
Our previous studies reported that one of the main mechanisms of the antitumor activity of simvastatin (SIM) in B16.F10 murine melanoma cells was associated with strong suppression of the constitutive cell production of the $\alpha$ subunit of the heterodimeric transcription factor hypoxia-inducible factor (HIF)-1. Thus, the present study aimed to broaden this finding under hypoxic conditions induced by incubation of B16.F10 cells with cobalt chloride, when the constitutive production of HIF-1 $\alpha$ in these melanoma cells is amplified by inducible expression of this factor. The data demonstrated that the SIM antiproliferative effects on melanoma cells were mediated mainly via strong suppressive actions on the B16.F10 cell capacity to support tumor angiogenesis and inflammation, as a result of a high inhibition of the inducible expression of HIF-1 $\alpha$. However, the constitutive expression of HIF-1 $\alpha$ was not affected by SIM, probably due to the lack of effect of this statin on nuclear factor- $\mathrm{kB}$ production in B16. F10 cancer cells at the concentration tested. Additionally, the present study noted slight reducing effects of SIM on tumor oxidative stress, which may contribute to the main inhibitory action of this statin on HIF-1 $\alpha$ production in hypoxic tumor cells. Collectively, these data are valuable for future anticancer strategies based on SIM administration in combination with cytotoxic drugs that are able to counteract the constitutive expression of HIF-1 $\alpha$ in tumors.
\end{abstract}

Correspondence to: Dr Manuela Banciu, Department of Molecular Biology and Biotechnology, Faculty of Biology and Geology, Babes-Bolyai University, 5-7 Clinicilor Street, 400006 Cluj-Napoca, Romania

E-mail: manuela.banciu@ubbcluj.ro

Key words: HIF-1, angiogenesis, inflammation, simvastatin, B16.F10 melanoma cells

\section{Introduction}

Our previous studies demonstrated that one of the main mechanisms of simvastatin (SIM) cytotoxic effects on B16.F10 murine melanoma cells under normoxic conditions is associated with the suppression of the constitutive tumor cell production of the $\alpha$ subunit of hypoxia inducible factor (HIF)-1 (1). The normoxic expression of HIF-1 via the constitutive activation of the Ras-Raf-mitogen-activated protein kinase kinase-extracellular signal-regulated kinase $1 / 2$ and phosphatidylinositol-4,5-bisphosphate 3-kinase-AKT signaling pathways ensures the maintenance of the malignant phenotype of highly metastatic melanoma cells (2-4). In addition, the production of HIF-1 in these malignant cells is further amplified by the hypoxic tumor microenvironment, suggesting that, under hypoxia, HIF-1 may activate different signaling pathways to promote cell survival and proliferation (5). Thus, hypoxia-induced HIF-1 $\alpha$ stabilization is followed by the activation of multiple genes encoding for proteins with critical functions in angiogenesis, cell proliferation, invasion, metastasis, genetic instability, cell survival, apoptosis, epithelial-mesenchymal transition and immune evasion (6-8).

The present study aimed to explore whether the mechanisms underlying the cytotoxicity of SIM on B16.F10 melanoma cells cultured under hypoxia also involved the modulation of HIF-1 $\alpha$ expression in these cancer cells. To mimic hypoxia, B16.F10 melanoma cells were cultured in the presence of cobalt chloride $\left(\mathrm{CoCl}_{2}\right)$, a chemical inducer of HIF-1 $\alpha$ stabilization $(9,10)$. The mechanisms of cytotoxicity exerted by SIM on B16.F10 cells grown in the presence of the $\mathrm{CoCl}_{2}$ were investigated with regard to tumor cell production of HIF-1 $\alpha$ and expression of proteins involved in main tumorigenic processes coordinated by this protein, including angiogenesis and inflammation $(11,12)$. Furthermore, as previous experimental data suggested that nuclear factor $(\mathrm{NF})-\kappa \mathrm{B}$ can also induce overexpression of HIF-1 $\alpha$ messenger RNA (13-15), the expression level of this protein was analyzed. In addition, the role of oxidative stress in SIM-induced cytotoxicity was evaluated. The results demonstrated that, under hypoxia, the main mechanism of SIM cytotoxicity in B16.F10 melanoma cells is 
mediated via inhibition of the chemically induced expression of HIF- $1 \alpha$ in these cancer cells. Additionally, and in accordance with the main function of the inducible production of this factor, the levels of proteins supporting tumor angiogenesis and inflammation were also strongly suppressed.

\section{Materials and methods}

Cell line and culture conditions. B16.F10 murine melanoma cells (CRL-6475; American Type Culture Collection, Manassas, VA, USA) were cultured in Dulbecco's modified Eagle's medium (Lonza Group Ltd., Basel, Switzerland) supplemented with $10 \%$ heat-inactivated fetal bovine serum (HyClone; GE Healthcare Life Sciences, Logan, UT, USA), $100 \mathrm{IU} / \mathrm{ml}$ penicillin, $100 \mu \mathrm{g} / \mathrm{ml}$ streptomycin, $0.25 \mu \mathrm{g} / \mathrm{ml}$ amphotericin B, 4 mM L-glutamine and 5\% $\mathrm{NaHCO}_{3}$ (Lonza Group Ltd.) as monolayer at $37^{\circ} \mathrm{C}$ in a $5 \% \mathrm{CO}_{2}$ humidified atmosphere. To obtain hypoxic conditions, cells were incubated in the above culture medium supplemented with several concentrations of $\mathrm{CoCl}_{2}(100,200$ and $300 \mu \mathrm{M})$. It was noticed that $200 \mu \mathrm{M} \mathrm{CoCl}_{2}$ was the minimum concentration that allowed the stimulation of the inducible expression of HIF-1 $\alpha$ without causing any cytotoxic effects on these cancer cells (data not shown).

Stock solutions of SIM. SIM (Sigma-Aldrich; Merck KGaA, Darmstadt, Germany) was dissolved in $70 \%$ ethanol to prepare stock solutions of $2 \mathrm{mg} / \mathrm{ml}$. Working solutions were prepared directly into the culture medium. As controls for ethanol toxicity, cells were incubated with ethanol at similar concentrations $(0.017-0.925 \%)$ as those used for the preparation of SIM working solutions.

Cell proliferation assay. To determine the effects of SIM on cell proliferation under normoxic and hypoxic conditions, B16.F10 melanoma cells (1,000 cells/well) were seeded in a 96-well plate for $24 \mathrm{~h}$. Different concentrations of SIM, ranging from 0.5 to $50 \mu \mathrm{g} / \mathrm{ml}$, were evaluated in triplicate. The range of statin concentrations was selected based on our previous study regarding the statin effects on B16.F10 cells (1). The cytotoxicity of the ethanol concentrations used for the preparation of the different SIM solutions was also assessed. Cells cultured either in medium or in medium supplemented with $200 \mu \mathrm{M} \mathrm{CoCl}_{2}$ were used as controls for normoxic and hypoxic conditions, respectively. The proliferative activity of the cells following statin administration was analyzed with an immunoassay [Cell Proliferation ELISA, BrdU (colorimetric); Roche Applied Science, Penzberg, Germany] according to the manufacturer's protocol $(16,17)$. This method is based on the incorporation of the pyridine analogue bromodeoxyuridine (BrdU), instead of thymidine, into the DNA of proliferating cells (16). B16.F10 melanoma cells were incubated with a BrdU solution for $24 \mathrm{~h}$, and the culture medium was then completely removed from each well. Following this step, the cells were fixed, and the DNA was denatured with FixDenat buffer provided in the kit. An anti-BrdU monoclonal antibody conjugated with peroxidase (anti-BrdU-POD, \#11647229001, Roche Applied Science, dilution, 1:100; part of Cell Proliferation ELISA, BrdU kit) was added in each well in order to detect the incorporated BrdU in the newly synthesized cellular DNA.
The antibody was removed after $1 \mathrm{~h}$ of incubation at room temperature, and the cells were then washed three times with PBS. Next, a peroxidase substrate (3,3',5,5'-tetramethylbenzidine, part of Cell Proliferation ELISA, BrdU kit) was added in each well, and the immune complexes were detected by measuring the absorbance of the reaction product at $450 \mathrm{~nm}$ with a reference wavelength of $655 \mathrm{~nm}$.

Viability assay. The cytotoxic effect of SIM was assessed using a colorimetric assay (CytoTox 96 Non-Radioactive Cytotoxicity Assay; Promega Corporation, Madison, WI, USA) based on the measurement of the catalytic activity of the lactate dehydrogenase (LDH) enzyme released in the culture medium (18). The assay was performed following the manufacturer's protocol. Briefly, B16.F10 melanoma cells $(5,000$ cells/well) were cultured in a 96-well plate for $24 \mathrm{~h}$ at $37^{\circ} \mathrm{C}$. Each statin concentration, ranging from 0.5 to $50 \mathrm{mg} / \mathrm{ml}$, was added in triplicate. The cytotoxicity of the ethanol concentrations used for the preparation of the different SIM solutions was also tested. Cells cultured either in medium or in medium with $200 \mu \mathrm{M} \mathrm{CoCl}{ }_{2}$ were used as controls for the spontaneous release of $\mathrm{LDH}$ under normoxic or hypoxic conditions, respectively. To determine the total release of $\mathrm{LDH}$ in the culture medium, $10 \mu \mathrm{l}$ of cell lysis buffer (part of the CytoTox 96 Non-Radioactive Cytotoxicity Assay kit) was added to the wells containing control cells for 45 min prior to harvesting the supernatant. At the end of the incubation period, the plate was centrifuged at $260 \times \mathrm{g}$, and $50 \mu \mathrm{l}$ of the culture medium from each well was transferred to an enzymatic assay plate and mixed with an equal volume of substrate mix (lactate and iodonitrotetrazolium violet, included in the CytoTox 96 Non-Radioactive Cytotoxicity Assay kit). After $30 \mathrm{~min}$ of incubation at room temperature, the reaction was stopped by adding the stop solution from the CytoTox 96 Non-Radioactive Cytotoxicity Assay kit, and the absorbance was measured at $490 \mathrm{~nm}$.

Western blot analysis of the expression of HIF-1 $\alpha$ and $N F-\kappa B$. The effects of $5 \mu \mathrm{g} / \mathrm{ml}$ SIM on the B16.F10 cell production of two key players in tumor cell survival, HIF-1 and NF- $\mathrm{B}$, was assessed by western blot analysis after $24 \mathrm{~h}$ of incubation at $37^{\circ} \mathrm{C}$. To obtain cell lysates (19-21), cells were washed with PBS, and viable (adherent) tumor cells were mechanically detached and lysed with cell lysis buffer [10 mM 4-(2-hydroxyethyl)-1-piperazineethanesulfonic acid, $200 \mathrm{mM} \mathrm{NaCl}, 1 \%$ Triton X-100, $10 \mathrm{mM} \mathrm{MgCl}_{2}$ and $1 \mathrm{mM}$ dithiothreitol] after $30 \mathrm{~min}$ of incubation on ice. cOmplete ${ }^{\mathrm{TM}}$ Protease Inhibitor Cocktail Tablets (Roche Applied Science) were added to the lysis buffer. Cells lysates were cleared by centrifugation at $18,000 \times \mathrm{g}$ for $10 \mathrm{~min}$ at $4^{\circ} \mathrm{C}$, and the supernatant was collected. The protein content of the cell lysates was determined by Bradford assay (Sigma-Aldrich; Merck KGaA). A total of $50 \mu \mathrm{g}$ of total protein was loaded per lane onto a $10 \%$ polyacrylamide gel. Electrophoresis was performed at $45 \mathrm{mV}$, and subsequently the proteins were electro-transferred onto a nitrocellulose membrane at $100 \mathrm{mV}$ for $40 \mathrm{~min}$. The membranes were blocked with $5 \%$ skimmed milk powder (Bio-Rad Laboratories, Inc., Hercules, CA, USA) in TBS containing $0.1 \%$ Tween-20 (TBS-T) for $3 \mathrm{~h}$ at room temperature. Subsequently, the membranes were incubated overnight 
at $4^{\circ} \mathrm{C}$ with rabbit polyclonal anti-HIF-1 $\alpha$ (NB100-479, Novus Biologicals, Ltd., Cambridge, UK) and mouse monoclonal anti-NF-кB antibodies (sc56735; Santa Cruz Biotechnology, Inc., Dallas, TX, USA), diluted 500-fold in 5\% skimmed milk powder in TBS-T. For the loading control, a primary rabbit polyclonal antibody against mouse $\beta$-actin (A2103; Sigma-Aldrich; Merck KGaA), diluted 1,000-fold in TBS-T, was used. To detect the bound antibodies, the membranes were washed with TBS-T and incubated with a goat anti-rabbit (sc-2004; Santa Cruz Biotechnology, Inc.) or a goat anti-mouse horseradish peroxidase (HRP)-conjugated secondary antibody (sc-2005; Santa Cruz Biotechnology, Inc.), diluted 4,000-fold in 5\% skimmed milk powder in TBS-T at room temperature for $2 \mathrm{~h}$. Proteins were detected using SuperSignal West Pico Chemiluminescent Substrate (Thermo Fisher Scientific, Inc., Waltham, MA, USA), and the membranes were exposed to an X-ray film (Kodak, Rochester, NY, USA) for $2 \mathrm{~min}$. The films were developed and analyzed using TotalLab Quant Software version 12 for Windows (TotalLab, Ltd., Newcastle upon Tyne, UK). Transcription factors levels in tumor cells treated with statin were compared to those in the controls. The final results are represented as the mean \pm standard deviation (SD) of two independent experiments.

Array analysis of inflammatory/angiogenic protein levels. To assess whether SIM could affect the tumor cell production of proteins involved in angiogenesis and inflammation, a screening using a protein array (AAM-ANG-1-8; RayBio ${ }^{\circledR}$ Mouse Angiogenesis Array C1; RayBiotech Inc., Norcross, GA, USA) was performed as described previously (22). The same tumor cell lysates as those employed in western blot analysis were used. One array membrane containing 24 types of primary antibodies against specific mouse proteins was used per cell lysate. The array membranes were incubated with $200 \mu \mathrm{g}$ of cell lysate proteins overnight at $4^{\circ} \mathrm{C}$. A mixture of secondary biotin-conjugated antibodies (included in the RayBio ${ }^{\circledR}$ Mouse Angiogenesis Array C1 kit) against the same angiogenic factors as those targeted by the aforementioned primary antibodies was added to the membranes and incubated for $2 \mathrm{~h}$ at room temperature, followed by incubation with HRP-conjugated streptavidin (included in the RayBio ${ }^{\circledR}$ Mouse Angiogenesis Array C1 kit) for additional $2 \mathrm{~h}$ at room temperature. Each incubation step was followed by five washing steps with two washing buffers included in the kit. Thereafter, the membranes were incubated with a mixture of two detection buffers (included in the RayBio ${ }^{\circledR}$ Mouse Angiogenesis Array $\mathrm{C} 1 \mathrm{kit}$ ) for $1 \mathrm{~min}$, exposed to an X-ray film (Kodak) for $1 \mathrm{~min}$, and then the films were developed. The protein expression level was quantified by measuring the intensity of the color of each spot on the membranes in comparison with the positive control spots already bound to the membranes using TotalLab Quant Software version 12 for Windows. Each protein level from the statin-treated groups was expressed as a percentage of the same protein level from the untreated cells (controls). Each protein from each experimental group was determined in duplicate.

High-performance liquid chromatography (HPLC) determination of malondialdehyde (MDA) levels. MDA is the main product of lipid peroxidation mediated by reactive oxygen species
(ROS), and therefore, it is a good indicator of overall oxidative stress (23). In the present study, MDA levels were determined according to the HPLC method employed by Karatas et al (24). Prior to HPLC quantification of MDA, sample deproteinization was performed as described previously (24). Then, samples were centrifuged at 4,500 $\mathrm{x} g$ for $5 \mathrm{~min}$, and $100 \mu \mathrm{l}$ of each supernatant was used for HPLC analysis. The column type was LiChrosorb ${ }^{\circledR}$ RP18 (5 $\left.\mu \mathrm{m}\right)$ (Sigma-Aldrich; Merck KGaA), and the mobile phase consisted of $30 \mathrm{mM} \mathrm{KH}_{2} \mathrm{PO}_{4}$ :methanol in a volume ratio of $65: 35$. The flow rate was set at $0.5 \mathrm{ml} / \mathrm{min}$, and MDA was measured using an ultraviolet detector set at $254 \mathrm{~nm}$. The retention time of MDA was $~ 5.4 \mathrm{~min}$. Data were expressed as $\mu \mathrm{mol}$ of $\mathrm{MDA} / \mathrm{mg}$ of protein.

Statistical analysis. Data from different experiments were reported as the mean \pm SD. SIM effects on tumor cells cultured with or without $\mathrm{CoCl}_{2}$ were analyzed by unpaired Student's t-test. To analyze the SIM effects on the levels of angiogenic/inflammatory proteins in cancer cells under both culture conditions, two-way analysis of variance with Bonferroni correction for multiple comparisons was used. All statistical analyses were performed with GraphPad Prism version 6 for Windows (GraphPad Software, Inc., La Jolla, CA, USA). P<0.05 was considered to indicate a statistically significant difference.

\section{Results}

SIM cytotoxicity in vitro. The cytotoxic effects of SIM were assessed with regard to B16.F10 cell proliferation and viability, and the results are shown in Figs. 1 and 2.

Effect of SIM on cell proliferation. To investigate the inhibitory effect of SIM on the proliferation of B16.F10 murine melanoma cells, these cells were incubated in the presence of $\mathrm{CoCl}_{2}$ with increasing concentrations of SIM ranging from 0.5 to $50 \mu \mathrm{g} / \mathrm{ml}$ for $24 \mathrm{~h}$ (Fig. 1). The proliferation rate of the cells incubated with the same concentrations of SIM under normoxic conditions was also assessed. Cells incubated only with culture medium or with culture medium supplemented with $200 \mu \mathrm{M}$ $\mathrm{CoCl}_{2}$ were used as controls. The cytotoxicity of the ethanol concentrations used for SIM solutions preparation was also tested. No inhibitory effect of any ethanol concentration on tumor cell proliferation was detected (Fig. 1).

The effect of SIM on cancer cell proliferation was expressed as the percentage of inhibition of cell proliferation compared with the proliferation of cells used as controls (Fig. 1). After $24 \mathrm{~h}$ of incubation, SIM inhibited cell proliferation by $>70 \%$ under normoxic and hypoxic conditions at concentrations ranging from 5 to $50 \mu \mathrm{g} / \mathrm{ml}$. Notably, under hypoxia, a moderate inhibitory effect of the statin ( 40-60\% compared with the proliferation of control cells) was also noted at the lowest drug concentrations tested $(0.5$ and $1 \mu \mathrm{g} / \mathrm{ml})$. However, since $5 \mu \mathrm{g} / \mathrm{ml}$ was the lowest concentration of SIM that exhibited a strong cytotoxic effect $(>70 \%$ inhibition of cell proliferation compared with the proliferation of control cells) (Fig. 1), this concentration was used throughout the experiments performed for testing the mechanisms of SIM cytotoxicity.

Effect of SIM on cell viability. The cytotoxic effect of different concentrations of SIM under both normoxic and hypoxic 


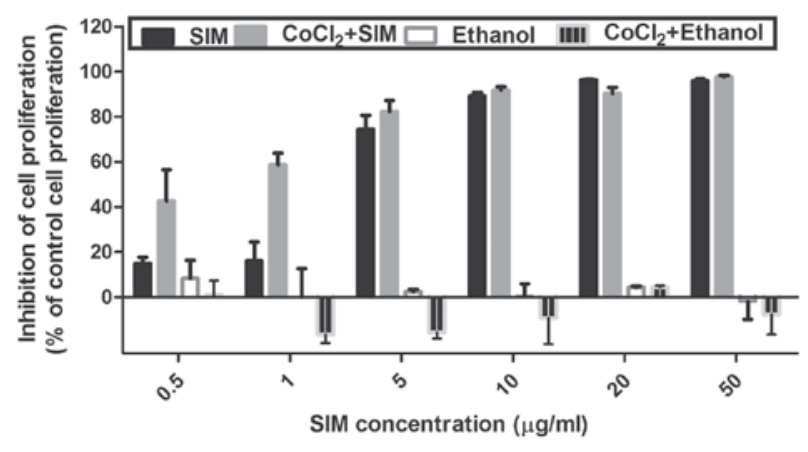

Figure 1. Effects of SIM on B16.F10 cell proliferation. B16.F10 mouse melanoma cells were incubated with different concentrations of SIM ranging from 0.5 to $50 \mu \mathrm{g} / \mathrm{ml}$ in the presence or absence of $200 \mu \mathrm{M} \mathrm{CoCl}_{2}$ for $24 \mathrm{~h}$. The cytotoxicity of the ethanol solution used for the preparation of each SIM concentration was also tested. Data are shown as the mean \pm standard deviation of three measurements and represented as percentages of proliferation inhibition compared with the proliferation of control cells. SIM, SIM-treated B16.F10 melanoma cells; $\mathrm{CoCl}_{2}+$ SIM, SIM-treated B16.F10 mouse melanoma cells incubated with $200 \mu \mathrm{M} \mathrm{CoCl}_{2}$; Ethanol, ethanol-treated B16.F10 melanoma cells; $\mathrm{CoCl}_{2}+$ Ethanol, ethanol-treated B16.F10 melanoma cells incubated with $200 \mu \mathrm{M} \mathrm{CoCl}_{2}$; SIM, simvastatin.

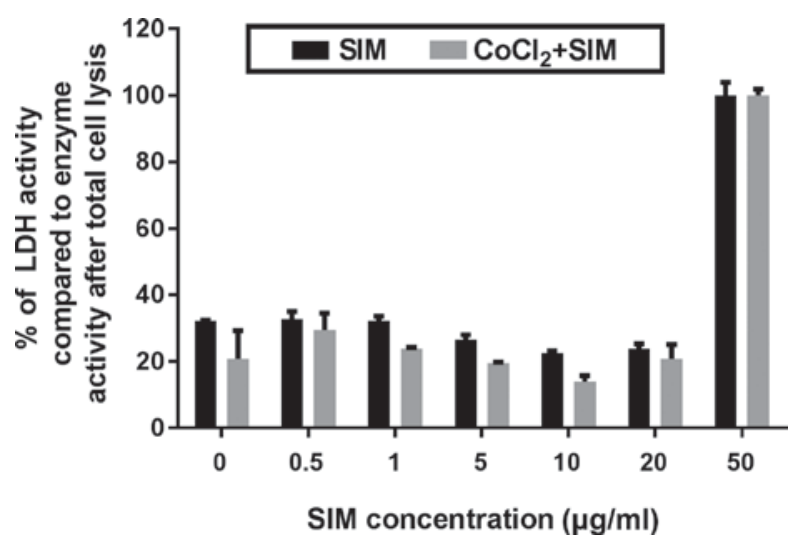

Figure 2. Effects of SIM on B16.F10 cell viability. B16.F10 mouse melanoma cells were incubated with different concentrations of SIM ranging from 0.5 to $50 \mu \mathrm{g} / \mathrm{ml}$ in the presence or absence of $200 \mu \mathrm{M} \mathrm{CoCl}_{2}$ for $24 \mathrm{~h}$. The results are expressed as percentages of catalytic activity of LDH released in the medium compared with the enzymatic activity in the same culture medium following total cell lysis. The reduction in viability of control cells (untreated cells cultured either in medium or in medium with $\mathrm{CoCl}_{2}$ ) is also shown (at $0 \mu \mathrm{g} / \mathrm{ml} \mathrm{SIM}$ ). Data are shown as the mean \pm standard deviation of three replicate measurements. SIM, SIM-treated B16.F10 melanoma cells; $\mathrm{CoCl}_{2}+$ SIM, SIM-treated B16.F10 melanoma cells incubated with $200 \mu \mathrm{M}$ $\mathrm{CoCl}_{2} ; \mathrm{SIM}$, simvastatin; LDH, lactate dehydrogenase.

conditions after $24 \mathrm{~h}$ of incubation were expressed as percentages of catalytic activity of LDH released in the culture medium. As shown in Fig. 2, the viability of tumor cells grown under normoxia or hypoxia was not affected by SIM at concentrations ranging from 0.5 to $20 \mu \mathrm{g} / \mathrm{ml}$. Only at the highest concentration of SIM tested $(50 \mu \mathrm{g} / \mathrm{ml})$, the viability of B16.F10 melanoma cells was totally affected (Fig. 2), since the activity of LDH released from these treated cells was similar to that determined upon cell lysis.

Effects of SIM on the expression levels of HIF-1 $\alpha$ and NF- $\kappa B$. Since HIF-1 and NF- $\mathrm{kB}$ serve key roles in the preservation of the malignant phenotype of cancer cells and in the survival mechanisms of tumor cells under critical conditions (25-27), the effects of $5 \mu \mathrm{g} / \mathrm{ml}$ SIM on the expression of both proteins in B16.F10 melanoma cells were evaluated. The results are shown in Figs. 3 and 4, respectively. As previously reported $(6,10)$, the present study confirmed that the addition of $200 \mu \mathrm{M} \mathrm{CoCl}_{2}$ to melanoma cells increased the expression level of HIF-1 $\alpha$ by $68 \%$ compared with its level in the same cells cultured under normoxia $(\mathrm{P}<0.05)$.

Under hypoxic conditions, SIM inhibited HIF-1 $\alpha$ expression by $50 \%$ compared with its production in the control hypoxic cells $(\mathrm{P}<0.05)$, while constitutive expression of this factor was not affected by the statin (Fig. 3B). Our previous results have shown that SIM inhibited strongly the constitutive expression of HIF-1 $\alpha$ in B16.F10 murine melanoma cells at a concentration 10-fold higher than that used in the present study (1). Regarding the production of NF- $\mathrm{\kappa B}$, SIM treatment did not affect the expression levels of this transcription factor under normoxic or hypoxic conditions (Fig. 4).

Effects of SIM on the angiogenic/inflammatory capacity of B16.F10 cells. As the production of one of the key regulatory factors of angiogenesis and inflammation, HIF-1 $\alpha$ (1), was inhibited by SIM treatment under hypoxia, this effect was associated with the levels of proteins involved in these tumorigenic processes in tumor cells. Therefore, a screening for 24 angiogenic and inflammatory proteins was performed via protein arrays (Tables I and II).

Notably, the mean average production of angiogenic and inflammatory proteins tested in cells cultured under $\mathrm{CoCl}_{2}$-induced hypoxia was significantly higher (by $26 \%$; $\mathrm{P}<0.05$ ) than their production in normoxic cells (cells in culture medium) (Fig. 5). Thus, the production of 11 out of 24 proteins was stimulated significantly under $\mathrm{CoCl}_{2}$ treatment. More specifically, the levels of pro-angiogenic proteins, including granulocyte-colony stimulating factor (G-CSF), macrophage-CSF (M-CSF), insulin-like growth factor (IGF)-II, monocyte chemoattractant protein (MCP)-1 and basic fibroblast growth factor (bFGF), were strongly stimulated in $\mathrm{CoCl}_{2}$-treated cells (by 50-100\%) compared with their production in control normoxic cells (Fig. 5). The levels of the anti-angiogenic and anti-inflammatory proteins platelet factor (PF)-4, tissue inhibitor of metalloproteinase (TIMP)-2 and interleukin (IL)-12p70 were also increased under $\mathrm{CoCl}_{2}$ treatment by $65-95 \%$ compared with their cell production in normoxic cells (Fig. 5). However, the cell production of important pro-angiogenic [vascular endothelial growth factor (VEGF)] and inflammatory (IL-1 $\beta$ and IL-6) proteins was reduced by $60 \%$ in hypoxic cells in comparison with their normoxic production (Fig. 5). When tumor cells were incubated with SIM under normoxic conditions, the overall production of pro-angiogenic/pro-inflammatory proteins was not affected by the statin treatment $(\mathrm{P}>0.05)$. Furthermore, incubation of the tumor cells only with SIM stimulated the production of IL-1 $\alpha$, IL-1 $\beta$ and MCP-1 by $15-30 \%$, while the expression of IL-12p40 and tumor necrosis factor (TNF)- $\alpha$ was stimulated by $60-80 \%$ (Table I). Only the level of the anti-angiogenic protein TIMP-2 was significantly reduced by $22 \%$ compared with its level in normoxic cells (Table II).

When SIM was administered to B16.F10 cells under hypoxia induced by $\mathrm{CoCl}_{2}$, the levels of all 
A

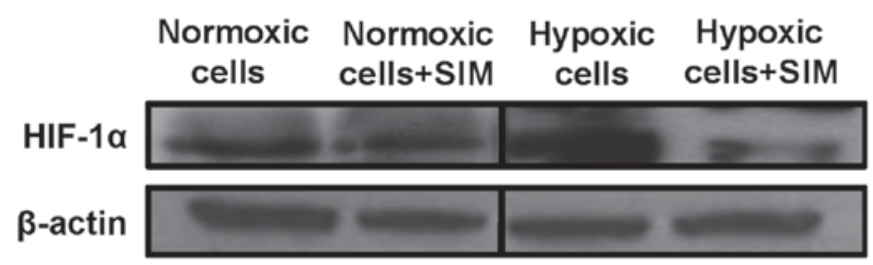

B
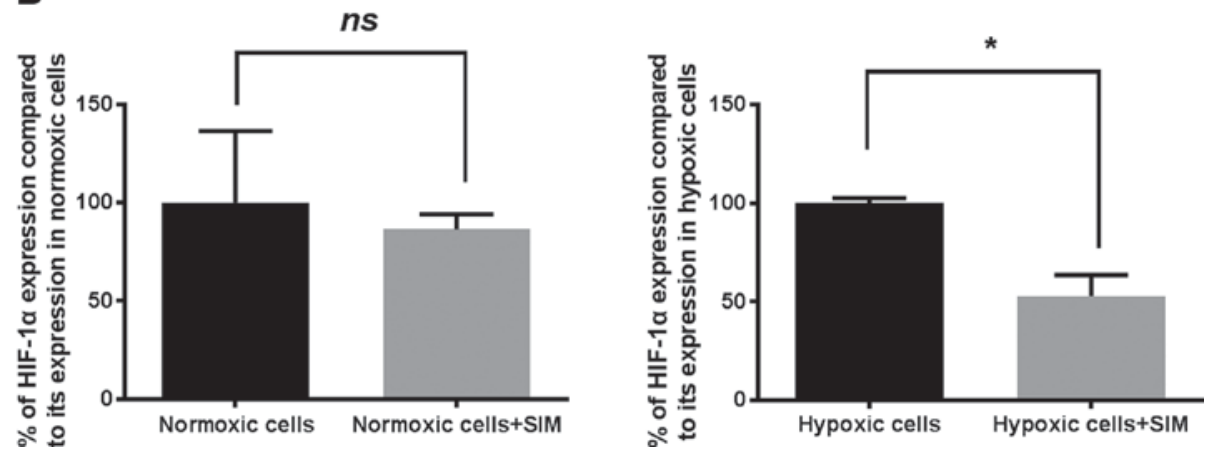

Figure 3. Effects of SIM treatment on HIF-1 $\alpha$ expression in B16.F10 melanoma cells. (A) Western blot analysis of HIF-1 $\alpha$ expression levels in normoxic and hypoxic B16.F10 cells after $24 \mathrm{~h}$ of incubation with $5 \mu \mathrm{g} / \mathrm{ml}$ SIM. (B) Percentages of HIF-1 $\alpha$ expression levels in B16.F10 cells after $24 \mathrm{~h}$ of incubation with $5 \mu \mathrm{g} / \mathrm{ml}$ SIM compared with its expression in control cells (either normoxic or hypoxic cells). The results represent the mean \pm standard deviation of two independent measurements. Unpaired Student's t-test was performed to analyze the effects of SIM on the tumor cell levels of HIF-1 $\alpha$. ${ }^{*} \mathrm{P}<0.05$. Normoxic cells, expression levels of HIF-1 $\alpha$ in control cells after $24 \mathrm{~h}$ of incubation with culture medium; Normoxic cells + SIM, expression levels of HIF-1 $\alpha$ in normoxic cells after $24 \mathrm{~h}$ of incubation with $5 \mu \mathrm{g} / \mathrm{ml} \mathrm{SIM}$; Hypoxic cells, expression levels of HIF-1 $\alpha$ in control cells after $24 \mathrm{~h}$ of incubation with medium supplemented with $200 \mu \mathrm{M} \mathrm{CoCl}_{2} ;$ Hypoxic cells + SIM, expression levels of HIF-1 $\alpha$ in hypoxic cells after $24 \mathrm{~h}$ of incubation with medium supplemented with $200 \mu \mathrm{M} \mathrm{CoCl}{ }_{2}$ and treated with $5 \mu \mathrm{g} / \mathrm{ml}$ SIM; ns, not significant; HIF, hypoxia-inducible factor; SIM, simvastatin.

A

\begin{tabular}{|c|c|c|c|c|}
\hline & $\begin{array}{l}\text { Normoxic } \\
\text { cells }\end{array}$ & $\begin{array}{l}\text { Normoxic } \\
\text { cells+SIM }\end{array}$ & $\begin{array}{c}\text { Hypoxic } \\
\text { cells }\end{array}$ & $\begin{array}{c}\text { Hypoxic } \\
\text { cells+SIM }\end{array}$ \\
\hline NF-kB & & - & & 0 \\
\hline actin & & & 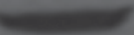 & $=$ \\
\hline
\end{tabular}
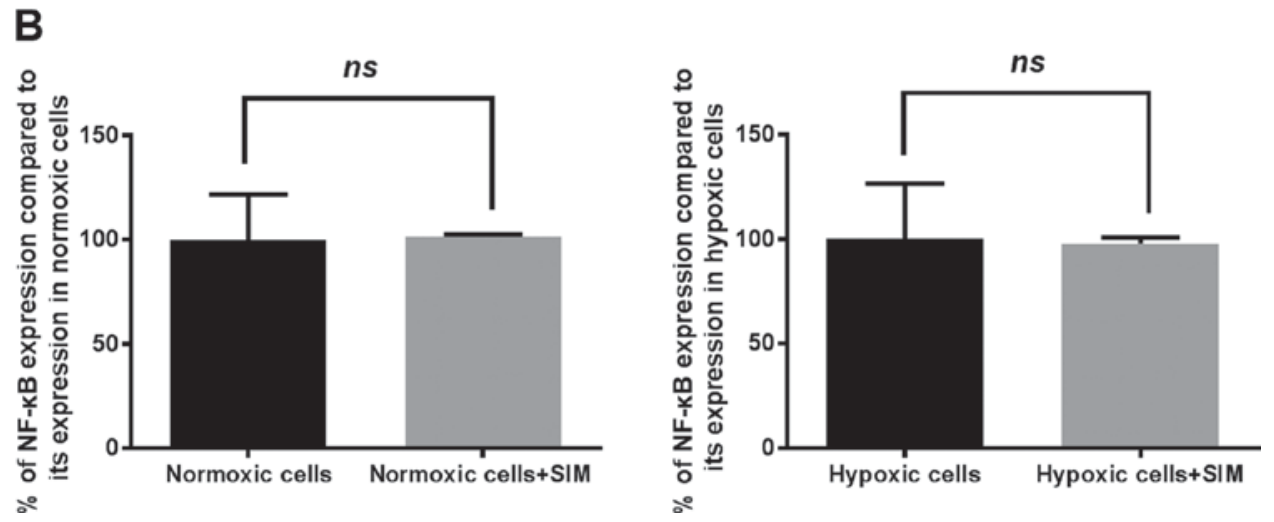

Figure 4. Effects of SIM treatment on NF-אB expression in B16.F10 melanoma cells. (A) Western blot analysis of NF- $\mathrm{KB}$ expression levels in normoxic and hypoxic B16.F10 cells after $24 \mathrm{~h}$ of incubation with SIM. (B) Percentages of NF- $\mathrm{KB}$ expression levels in B16.F10 cells after $24 \mathrm{~h}$ of incubation with $5 \mu \mathrm{g} / \mathrm{ml}$ SIM compared with its expression levels in control cells (either normoxic or hypoxic cells). The results represent the mean \pm standard deviation of two independent measurements. Unpaired Student's $t$ test was performed to analyze the effects of SIM on tumor cell levels of the transcription factor NF-kB. Normoxic cells, expression levels of NF- $\mathrm{KB}$ in control cells after $24 \mathrm{~h}$ of incubation with culture medium; Normoxic cells + SIM, expression levels of NF- $\mathrm{\kappa} B$ in normoxic cells after $24 \mathrm{~h}$ of incubation with $5 \mu \mathrm{g} / \mathrm{ml} \mathrm{SIM}$; Hypoxic cells, expression levels of NF- $\mathrm{kB}$ in control cells after $24 \mathrm{~h}$ of incubation with medium supplemented with $200 \mu \mathrm{M} \mathrm{CoCl}_{2} ;$ Hypoxic cells $+\mathrm{SIM}$, expression levels of NF-kB in hypoxic cells after $24 \mathrm{~h}$ of incubation with medium supplemented with $200 \mu \mathrm{M} \mathrm{CoCl}{ }_{2}$ and treated with $5 \mu \mathrm{g} / \mathrm{ml}$ SIM; ns, not significant; SIM, simvastatin; NF, nuclear factor.

pro-angiogenic/pro-inflammatory proteins were reduced significantly (Table I), with an overall inhibitory effect of $75 \%(\mathrm{P}<0.0001)$ compared with the production of these proteins in hypoxic cells. More specifically, SIM reduced strongly (by $70-85 \%$ ) the production of 16 out of 18 pro-angiogenic/pro-inflammatory proteins (including 
Table I. Effects of $5 \mu \mathrm{g} / \mathrm{ml} \mathrm{SIM} \mathrm{on} \mathrm{B16.F10} \mathrm{melanoma} \mathrm{cell} \mathrm{production} \mathrm{of} \mathrm{pro-angiogenic/pro-inflammatory} \mathrm{proteins} \mathrm{under}$ normoxic and hypoxic conditions.

Percentage of reduction (-) or increase (+) in tumor cell production of proteins involved in tumorangiogenesis/ inflammation following SIM treatment, mean \pm SD

Pro-angiogenic/pro-inflammatory proteins

\begin{tabular}{cc}
\hline SIM & $\mathrm{COCl}_{2}+$ SIM \\
$+19 \pm 18.12^{\mathrm{a}}$ & $-83.19 \pm 0.54^{\mathrm{d}}$ \\
$+22.41 \pm 13.20^{\mathrm{a}}$ & $-74.00 \pm 1.09^{\mathrm{d}}$ \\
$+9.27 \pm 0.78^{\mathrm{a}}$ & $-82.80 \pm 0.13^{\mathrm{d}}$ \\
$+4.60 \pm 2.16^{\mathrm{a}}$ & $-82.37 \pm 0.22^{\mathrm{d}}$ \\
$+18.00 \pm 0.01^{\mathrm{b}}$ & $-73.90 \pm 0.50^{\mathrm{d}}$ \\
$+22.70 \pm 0.93^{\mathrm{c}}$ & $-72.64 \pm 0.51^{\mathrm{d}}$ \\
$+13.63 \pm 5.36^{\mathrm{a}}$ & $-85.52 \pm 0.04^{\mathrm{d}}$ \\
$+7.92 \pm 1.27^{\mathrm{a}}$ & $-71.40 \pm 0.35^{\mathrm{d}}$ \\
$+80.89 \pm 11.48^{\mathrm{d}}$ & $-83.26 \pm 0.73^{\mathrm{d}}$ \\
$+6.19 \pm 2.86^{\mathrm{a}}$ & $-75.42 \pm 0.78^{\mathrm{d}}$ \\
$+58.87 \pm 29.45^{\mathrm{c}}$ & $-83.98 \pm 0.17^{\mathrm{d}}$ \\
$+24.07 \pm 3.21^{\mathrm{c}}$ & $-82.65 \pm 0.14^{\mathrm{d}}$ \\
$-4.09 \pm 3.11^{\mathrm{a}}$ & $-47.31 \pm 0.86^{\mathrm{b}}$ \\
$+5.91 \pm 17.93^{\mathrm{a}}$ & $-74.8 \pm 0.19^{\mathrm{d}}$ \\
$+22.68 \pm 7.57^{\mathrm{a}}$ & $-85.19 \pm 0.06^{\mathrm{d}}$ \\
$+0.92 \pm 23.31^{\mathrm{a}}$ & $-72.22 \pm 0.66^{\mathrm{b}}$ \\
$+8.64 \pm 13.19^{\mathrm{a}}$ & $-56.23 \pm 1.39^{\mathrm{a}}$ \\
$-7.03 \pm 11.62^{\mathrm{a}}$ & $-80.83 \pm 0.32^{\mathrm{d}}$
\end{tabular}

Granulocyte-colony stimulating factor

Granulocyte-macrophage-colony stimulating factor

Macrophage-colony stimulating factor

Insulin growth factor II

Interleukin $1 \alpha$

Interleukin $1 \beta$

Interleukin 6

Interleukin 9

Interleukin 12 p40

Interleukin 13

Tumor necrosis factor $\alpha$

Monocyte chemoattractant protein-1

Eotaxin

Fas ligand

Basic fibroblast growth factor

Vascular endothelial growth factor

Leptin

Thrombopoietin

$-83.19 \pm 0.54^{d}$
$-74.00 \pm 1.09^{d}$
$-82.80 \pm 0.13^{d}$
$-82.37 \pm 0.22^{d}$
$-73.90 \pm 0.50^{d}$
$-72.64 \pm 0.51^{d}$
$-85.52 \pm 0.04^{d}$
$-71.40 \pm 0.35^{d}$
$-83.26 \pm 0.73^{d}$
$-75.42 \pm 0.78^{d}$
$-83.98 \pm 0.17^{d}$
$-82.65 \pm 0.14^{d}$
$-47.31 \pm 0.86^{b}$
$-74.8 \pm 0.19^{d}$
$-85.19 \pm 0.06^{d}$
$-72.22 \pm 0.66^{b}$
$-56.23 \pm 1.39^{a}$
$-80.83 \pm 0.32^{d}$

The results represent the mean $\pm \mathrm{SD}$ of two independent measurements. ${ }^{\mathrm{a} N o t}$ significant; ${ }^{\mathrm{b}} \mathrm{P}<0.05 ;{ }^{\mathrm{c}} \mathrm{P}<0.01$; ${ }^{\mathrm{d}} \mathrm{P}<0.001$. SIM, percentages of reduction (-) or increase (+) in protein production in C26 cells incubated with $5 \mu \mathrm{g} / \mathrm{ml} \mathrm{SIM} \mathrm{for} 24 \mathrm{~h}$ compared with their normoxic production in untreated cells; $\mathrm{CoCl}_{2}+\mathrm{SIM}$, percentages of reduction (-) or increase (+) in protein production in C26 cells incubated with $200 \mu \mathrm{M} \mathrm{CoCl}_{2}$ and $5 \mu \mathrm{g} / \mathrm{ml} \mathrm{SIM}$ for $24 \mathrm{~h}$ compared with their production in cells treated only with $\mathrm{CoCl}_{2}$. SIM, simvastatin; SD, standard deviation.

Table II. Effects of $5 \mu \mathrm{g} / \mathrm{ml} \mathrm{SIM} \mathrm{on} \mathrm{B16.F10} \mathrm{melanoma} \mathrm{cell} \mathrm{production} \mathrm{of} \mathrm{anti-angiogenic/anti-inflammatory} \mathrm{proteins} \mathrm{under}$ normoxic and hypoxic conditions.

Percentage of reduction (-) and increase (+) in tumor cell production of proteins involved in tumor angiogenesis/ inflammation following SIM treatment, mean \pm SD

Anti-angiogenic/anti-inflammatory proteins

SIM

$-6.75 \pm 9.18^{\mathrm{a}}$

$-22.72 \pm 6.18^{\mathrm{b}}$

$+14.25 \pm 8.11^{\mathrm{a}}$

$+9.87 \pm 2.60^{\mathrm{a}}$

$+17.15 \pm 3.92^{\mathrm{a}}$

$+10.19 \pm 1.04^{\mathrm{a}}$
$\mathrm{CoCl}_{2}+\mathrm{SIM}$

$-78.13 \pm 0.47^{\mathrm{c}}$

$-82.97 \pm 0.10^{c}$

$-82.13 \pm 0.17^{\mathrm{c}}$

$-82.32 \pm 0.26^{\mathrm{c}}$

$-82.32 \pm 0.41^{\mathrm{c}}$

$-25.09 \pm 1.41^{\mathrm{a}}$

Monokine induced by interferon $\gamma$

The results represent the mean $\pm \mathrm{SD}$ of two independent measurements. ${ }^{\mathrm{a} N o t}$ significant; ${ }^{\mathrm{b}} \mathrm{P}<0.05 ;{ }^{\mathrm{c}} \mathrm{P}<0.001$. SIM, percentages of reduction (-) or increase $(+)$ in protein production in C26 cells incubated with $5 \mu \mathrm{g} / \mathrm{ml} \mathrm{SIM} \mathrm{for} 24 \mathrm{~h}$ compared with their normoxic production in untreated cells; $\mathrm{CoCl}_{2}+\mathrm{SIM}$, percentages of reduction (-) or increase (+) in protein production in C26 cells incubated with $200 \mu \mathrm{M} \mathrm{CoCl}_{2}$ and $5 \mu \mathrm{g} / \mathrm{ml}$ $\mathrm{SIM}$ for $24 \mathrm{~h}$ compared with their production in cells treated only with $\mathrm{CoCl}_{2}$. SIM, simvastatin; SD, standard deviation.

G-CSF, GM-CSF, M-CSF, IGF-II, IL-1 $\alpha$, IL-1 $\beta$, IL-6, IL-9, IL-12p40, IL-13, TNF- $\alpha$, MCP-1, Fas ligand, VEGF, bFGF and thrombopoietin) and moderately (by 45-60\%) that of leptin and eotaxin (Table I). However, with the exception 


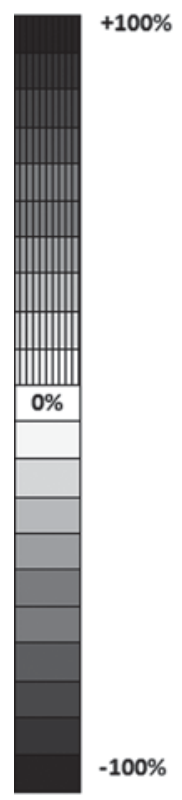

\begin{tabular}{|c|c|c|}
\hline & $\begin{array}{l}\text { Hypoxic } \\
\text { cells }\end{array}$ & \\
\hline G-CSF & & \multirow{18}{*}{ 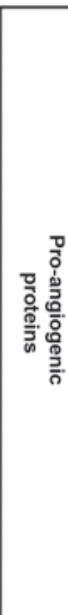 } \\
\hline GM-CSF & & \\
\hline M-CSF & & \\
\hline IGF-II & & \\
\hline IL-1a & & \\
\hline IL-1 $1 \beta$ & & \\
\hline IL-6 & & \\
\hline IL-9 & & \\
\hline IL-12p40 & & \\
\hline IL-13 & & \\
\hline TNF- $\alpha$ & & \\
\hline $\begin{array}{l}\text { Monocyte } \\
\text { chemoattractant } \\
\text { protein-1 }\end{array}$ & & \\
\hline Eotaxin & & \\
\hline Fast & & \\
\hline bFGF & & \\
\hline VEGF & & \\
\hline Leptin & & \\
\hline Thrombopoietin & & \\
\hline TIMP-1 & & \multirow{6}{*}{ 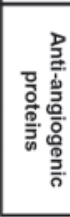 } \\
\hline TIMP-2 & & \\
\hline \begin{tabular}{|l|} 
Platelet factor- \\
\end{tabular} & & \\
\hline IL-12p70 & & \\
\hline IFN- $\gamma$ & & \\
\hline $\begin{array}{l}\text { Monokine } \\
\text { induced by IFNy }\end{array}$ & & \\
\hline
\end{tabular}

Figure 5. Effects of $\mathrm{CoCl}_{2}$-induced hypoxia on the production of angiogenic/inflammatory proteins in B16.F10 melanoma cells. Results are presented either as a percentage of reduction in tumor protein levels ranging from $0 \%$ (white) to $100 \%$ (black), or as percentage of increase in protein production ranging from $0 \%$ (white with vertical line pattern) to $100 \%$ (black with vertical line pattern) in cells treated with $\mathrm{CoCl}_{2}$ compared with the levels of the same proteins in normoxic cells. Hypoxic cells, percentages of protein expression levels in B16.F10 melanoma cells after incubation with $200 \mu \mathrm{M} \mathrm{CoCl}_{2}$ for $24 \mathrm{~h}$ compared with their levels in normoxic cells; G-CSF, granulocyte-colony stimulating factor; M-CSF, macrophage-colony stimulating factor; IGF, insulin-like growth factor; IL, interleukin; TNF tumor necrosis factor; FasL, Fas ligand; bFGF, basic fibroblast growth factor; VEGF, vascular endothelial growth factor; TIMP, tissue inhibitor of metalloproteinase; IFN, interferon.

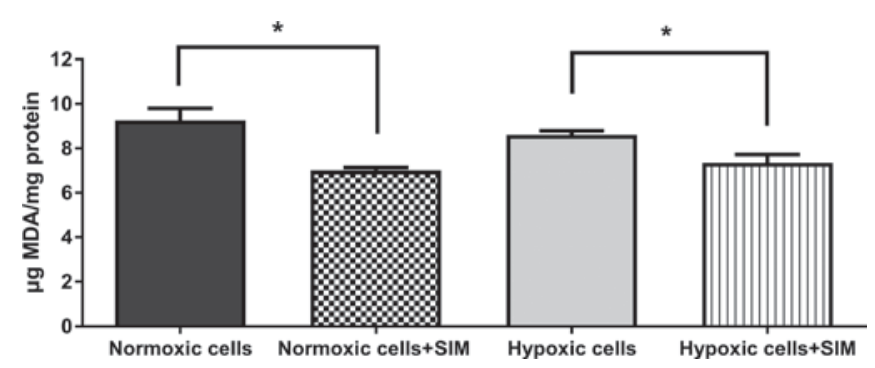

Figure 6. Evaluation of SIM effects on oxidative stress in B16.F10 melanoma cells. MDA levels were determined by high-performance liquid chromatography analysis. The results are expressed as the mean \pm standard deviation of two independent measurements. Unpaired Student's $t$ test was performed to analyze the differences between MDA levels in SIM-treated and control cells. ${ }^{*} \mathrm{P}<0.05$. Normoxic cells, MDA levels in untreated cells after $24 \mathrm{~h}$ of incubation with culture medium; Normoxic cells + SIM, MDA levels in normoxic cells after $24 \mathrm{~h}$ of incubation with $5 \mu \mathrm{g} / \mathrm{ml}$ SIM; Hypoxic cells, MDA levels in cells after $24 \mathrm{~h}$ of incubation with medium supplemented with $200 \mu \mathrm{M} \mathrm{CoCl}_{2} ;$ Hypoxic cells + SIM, MDA levels in cells after $24 \mathrm{~h}$ of incubation with medium supplemented with $200 \mu \mathrm{M} \mathrm{CoCl}_{2}$ and treated with $5 \mu \mathrm{g} / \mathrm{ml}$ SIM; SIM, simvastatin; MDA, malondialdehyde.

of monokine induced by gamma interferon (MIG), the cell production of all the anti-angiogenic proteins was also inhibited strongly (by 78-82\%) by SIM treatment following $\mathrm{CoCl}_{2}$ administration (Table II).
SIM effect on intracellular oxidative stress. To evaluate whether SIM treatment affected intracellular oxidative stress in murine melanoma cells cultured under normoxic and hypoxic conditions, the levels of MDA (a general marker for oxidative stress in tumor cells) (24) were determined. The data revealed that $5 \mu \mathrm{g} / \mathrm{ml}$ SIM significantly inhibited $(\mathrm{P}<0.05)$ the production of MDA in B16.F10 melanoma cells by $15-25 \%$ under both conditions (Fig. 6). Therefore, the anti-oxidant activity of SIM may complement the antitumor effects of this statin on the expression levels of HIF- $1 \alpha$, and angiogenic and inflammatory proteins in B16.F10 melanoma cells.

\section{Discussion}

The present study provides a follow-up of our earlier observations that inhibition of the constitutive expression of HIF-1 $\alpha$ in B16.F10 murine melanoma cells is one of the main reasons behind the cytotoxicity caused by lipophilic statins on these cancer cells (1). Therefore, the present study evaluated whether this finding could be expanded under hypoxic conditions, when the constitutive production of HIF-1 $\alpha$ in B16.F10 melanoma cells is accompanied by its induced expression as a result of $\mathrm{CoCl}_{2}$-mediated transcription factor stabilization and activation (28). To the best of our knowledge, these statin effects on melanoma cells under hypoxic conditions have not been previously described. As expected, culture of melanoma cells in the presence of $\mathrm{CoCl}_{2}$ increased the expression level of HIF- $1 \alpha$ by $68 \%$ compared with its expression in normoxic cells (Fig. 3A). It is known that hypoxia-induced expression of this protein in cancer cells triggers the upregulation of numerous genes encoding for proteins involved in tumorigenic processes, including angiogenesis, invasion, metastasis, cell proliferation, genetic instability, cell survival, apoptosis, epithelial-mesenchymal transition and immune evasion (29). Thus, this considerable number of tumorigenic processes controlled by HIF-1 may be affected simultaneously by the targeting of SIM to suppress this key regulatory protein expression in melanoma cells. In line with previous results regarding SIM cytotoxicity in B16.F10 melanoma cells under normoxia $(1,30)$, SIM also inhibited strongly the proliferation of hypoxic melanoma cells at concentrations ranging from 5 to $50 \mu \mathrm{g} / \mathrm{ml}$ (Fig. 1). However, the viability of melanoma cells was affected only at the highest SIM concentration tested $(50 \mu \mathrm{g} / \mathrm{ml})$ (Fig. 2), suggesting a limited cytotoxicity of SIM on these cancer cells. To further investigate the link between the mechanisms of SIM-induced cytotoxicity in B16.F10 melanoma cells under hypoxia and targeting of HIF- $1 \alpha$, the cell expression levels of this protein were assessed. After $24 \mathrm{~h}$ of incubation with $5 \mu \mathrm{g} / \mathrm{ml} \mathrm{SIM}$, the cell production of HIF-1 $\alpha$ was reduced by $50 \%$ in hypoxic cells (Fig. 3B), while the same concentration of SIM added to normoxic cells had no effect on the B16.F10 cell expression of this transcription factor subunit (Fig. 3A and B). This finding suggested that $5 \mu \mathrm{g} / \mathrm{ml}$ SIM was not sufficient to abolish the constitutive expression of HIF-1 $\alpha$ in B16.F10 melanoma cells, as its production in normoxic cells was not affected by this treatment (Fig. 3A and B). An explanation for this result may be due to the lack of effects of SIM on the expression of NF- $\kappa B$ (Fig. 4). The persistent $\mathrm{NF}-\kappa \mathrm{B}$ expression in SIM-treated tumor cells may represent an escape mechanism for maintaining the basal levels of 
HIF-1 $\alpha$ in highly metastatic cancer cells, since NF- $\kappa \mathrm{B}$ is a direct modulator of HIF-1 $\alpha$ expression at both transcriptional and post-translational levels $(14,31)$. However, since previous studies demonstrated that the hypoxic switch from the proliferative phenotype of melanoma cells to an invasive pattern is dependent on HIF-1 $\alpha$ tumor cell production (9), the SIM-mediated suppression of HIF-1 $\alpha$ production may suggest that this statin is able to control the metastatic capacity of B16.F10 cells.

To link the inhibitory actions of SIM on HIF-1 $\alpha$ production with the statin actions on the capacity of tumor cells to support vital processes for tumor survival $(12,32), 24$ proteins involved in angiogenesis and inflammation were assessed in the present study (Fig. 5 and Tables I and II). As expected, overexpression of HIF-1 $\alpha$ following $\mathrm{CoCl}_{2}$ treatment stimulated the levels of the majority of pro-angiogenic and pro-inflammatory proteins, with the highest enhancement observed in the production of G-CSF, M-CSF, IGF-II, MCP-1 and bFGF (Fig. 5). Among these proteins, bFGF (whose whole levels upon $\mathrm{CoCl}_{2}$ treatment increased by $100 \%$ in comparison with its control levels) is considered one of the most powerful angiogenic factors in cancer cells regulated by HIF-1 $\alpha$ (33-35). By contrast, the expression levels of the key pro-angiogenic protein VEGF and important pro-inflammatory cytokines such as IL-6 and IL-1 $\beta$ were strongly reduced (by 60\%) in B16.F10 cells treated with $\mathrm{CoCl}_{2}$, suggesting that not all pro-angiogenic/pro-inflammatory pathways are equally modulated in these cancer cells (36). In addition, the expression of MIG, an angiostatic protein (37), was suppressed by $60 \%$ upon hypoxic induction of HIF-1 $\alpha$ production. However, probably as a compensatory mechanism for this effect, the levels of the anti-angiogenic proteins PF-4, TIMP-2 and IL-12p70 were also increased in cells treated with $\mathrm{CoCl}_{2}(10)$.

When SIM was administered to normoxic melanoma cells, the overall production of pro-angiogenic proteins was not affected (Table I). This finding may be associated with the inability of SIM to affect the constitutive expression of HIF-1 $\alpha$ in melanoma cells (Fig. 3A). Unexpectedly, SIM administrated concomitantly with $\mathrm{CoCl}_{2}$ to tumor cells induced a $\sim 75 \%$ reduction in pro-angiogenic factors (Table I). This beneficial effect is clearly associated with the inhibitory effect of SIM on the hypoxia-induced cell production of HIF-1 $\alpha$ (Fig. 3B), which is the most important regulator of tumor angiogenesis (32). However, the cell production of the majority of anti-angiogenic proteins was strongly inhibited by SIM treatment in the presence of $\mathrm{CoCl}_{2}$ (Table II). This effect may be associated with the suppressive effects of SIM exerted on other transcription factors (such as activator protein-1) that control the expression of the genes encoding for these proteins $(38,39)$. Since there is a tight correlation between HIF-1 $\alpha$ expression and oxidative stress intensity $(40,41)$, and a large body of data demonstrated the role of SIM in the modulation of tumor oxidative stress $(1,42,43)$, the current study assessed a general marker for tumor oxidative stress, MDA. The results indicated that $5 \mu \mathrm{g} / \mathrm{ml}$ SIM slightly reduced the levels of ROS in melanoma cells under both normoxia and hypoxia (Fig. 6). Although this beneficial effect is modest, it may contribute to amplify the main inhibitory action of SIM on the HIF- $1 \alpha$-activated angiogenic and inflammatory capacity of melanoma cells.
In summary, the present data suggested that targeting HIF-1 $\alpha$ by SIM in hypoxic melanoma cells induced a strong antitumor response via inhibition of crucial regulators of tumorigenic processes such as cell proliferation, angiogenesis and inflammation. It is worth mentioning that the SIM concentration used in the present study can be easily achieved in vivo, thus overcoming one of the main limitations of statin use for cancer therapy (44). Although SIM was not able to inhibit the constitutive expression of HIF-1 $\alpha$, the current data may be valuable for future antitumor strategies based on the combination of this lipophilic statin with drugs that can counteract the escape mechanisms used by these tumor cells. Thus, inhibitors of $\mathrm{NF}-\kappa \mathrm{B}$ production in melanoma cells such as NEMO-binding domain peptide selective inhibitor and bortezomib $(45,46)$ may suppress indirectly the constitutive levels of HIF-1 $\alpha$ in cancer cells and help to improve future anticancer therapies based on lipophilic statins.

\section{Acknowledgements}

The present study was supported by grants from the Romanian National Authority for Scientific Research and Innovation (project number PN-II-RU-TE-2014-4-1191; contract number 235/2015) and the Babes-Bolyai University (project code GTC_34033/2013). The present manuscript is the result of a post-doctoral research study conducted thanks to the financial support of the Sectoral Operational Program for Human Resources Development 2007-2013, which was co-financed by the European Social Fund under the project POSDRU/159/1.5/S/133391 (project title 'Doctoral and postdoctoral excellence programs for training highly qualified human resources for research in the fields of Life Sciences, Environment and Earth'). The open access publication fee for the present study was covered by the national project PN-II-RU-TE-2014-4-1191 (contract number 235/2015).

\section{References}

1. Alupei MC, Licarete E, Cristian FB and Banciu M: Cytotoxicity of lipophilic statins depends on their combined actions on HIF-1 $\alpha$ expression and redox status in B16.F10 melanoma cells. Anticancer Drugs 25: 393-405, 2014.

2. Mills CN, Joshi SS and Niles RM: Expression and function of hypoxia inducible factor- 1 alpha in human melanoma under non-hypoxic conditions. Mol Cancer 8: 104, 2009.

3. Yajima I, Kumasaka MY, Thang ND, Goto Y, Takeda K, Yamanoshita O, Iida M, Ohgami N, Tamura H, Kawamoto Y and Kato M: RAS/RAF/MEK/ERK and PI3K/PTEN/AKT signaling in malignant melanoma progression and therapy. Dermatol Res Pract 2012: 354191, 2012.

4. Kuphal S, Winklmeier A, Warnecke $C$ and Bosserhoff AK: Constitutive HIF-1 activity in malignant melanoma. Eur J Cancer 46: 1159-1169, 2010.

5. Masson $\mathrm{N}$ and Ratcliffe PJ: Hypoxia signaling pathways in cancer metabolism: The importance of co-selecting interconnected physiological pathways. Cancer Metab 2: 3, 2014.

6. Kallio PJ, Wilson WJ, O'Brien S, Makino Y and Poellinger L: Regulation of the hypoxia-inducible transcription factor lalpha by the ubiquitin-proteasome pathway. J Biol Chem 274: 6519-6525, 1999.

7. Kaelin WG Jr and Ratcliffe PJ: Oxygen sensing by metazoans: The central role of the HIF hydroxylase pathway. Mol Cell 30: 393-402, 2008

8. Semenza GL:Hypoxia-inducible factor 1 and cancer pathogenesis. IUBMB Life 60: 591-597, 2008. 
9. Widmer DS, Hoek KS, Cheng PF, Eichhoff OM, Biedermann T, Raaijmakers MI, Hemmi S, Dummer R and Levesque MP: Hypoxia contributes to melanoma heterogeneity by triggering HIF1 $\alpha$-dependent phenotype switching. J Invest Dermatol 133: 2436-2443, 2013.

10. Rodrigues $\mathrm{M}$, Xin X, Jee K, Babapoor-Farrokhran S, Kashiwabuchi F, Ma T, Bhutto I, Hassan SJ, Daoud Y, Baranano D, et al: VEGF secreted by hypoxic Müller cells induces MMP-2 expression and activity in endothelial cells to promote retinal neovascularization in proliferative diabetic retinopathy. Diabetes 62: 3863-3873, 2013.

11. Krock BL, Skuli N and Simon MC: Hypoxia-induced angiogenesis: Good and evil. Genes Cancer 2: 1117-1133, 2011.

12. Ling FC, Khochfar J, Baldus SE, Brabender J, Drebber U, Bollschweiler E, Hoelscher AH and Schneider PM: HIF-1alpha protein expression is associated with the environmental inflammatory reaction in Barrett's metaplasia. Dis Esophagus 22: 694-699, 2009.

13. Nakayama K: cAMP-response element-binding protein (CREB) and $\mathrm{NF}-\kappa \mathrm{B}$ transcription factors are activated during prolonged hypoxia and cooperatively regulate the induction of matrix metalloproteinase MMP1. J Biol Chem 288: 22584-22595, 2013.

14. van Uden P, Kenneth NS and Rocha S: Regulation of hypoxia-inducible factor-1alpha by NF-kappaB. Biochem J 412: 477-484, 2008

15. Culver C, Sundqvist A, Mudie S, Melvin A, Xirodimas D and Rocha S: Mechanism of hypoxia-induced NF-kappaB. Mol Cell Biol 30: 4901-4921, 2010

16. Gratzner HG: Monoclonal antibody to 5-bromo- and 5-iododeoxyuridine: A new reagent for detection of DNA replication. Science 218: 474-475, 1982

17. Coimbra M, Banciu M, Fens MH, de Smet L, Cabaj M, Metselaar JM, Storm G and Schiffelers RM: Liposomal pravastatin inhibits tumor growth by targeting cancer-related inflammation. J Control Release 148: 303-310, 2010

18. Singer CA, Figueroa-Masot XA, Batchelor RH and Dorsa DM: The mitogen-activated protein kinase pathway mediates estrogen neuroprotection after glutamate toxicity in primary cortical neurons. J Neurosci 19: 2455-2463, 1999.

19. Yang L, Xiao M, Li X, Tang Y and Wang YL: Arginine ADP-ribosyltransferase 1 promotes angiogenesis in colorectal cancer via the PI3K/Akt pathway. Int J Mol Med 37: 734-742, 2016.

20. Kim J, Shao Y, Kim SY, Kim S, Song HK, Jeon JH, Suh HW, Chung JW, Yoon SR, Kim YS and Choi I: Hypoxia-induced IL-18 increases hypoxia-inducible factor-1alpha expression through a Racl-dependent NF-kappaB pathway. Mol Biol Cell 19: 433-444, 2008.

21. Shi Y, Chang M, Wang F, Ouyang X, Jia Y and Du H: Role and mechanism of hypoxia-inducible factor-1 in cell growth and apoptosis of breast cancer cell line MDA-MB-231. Oncol Lett 1: 657-662, 2010

22. Banciu M, Schiffelers RM, Fens MH, Metselaar JM and Storm G: Anti-angiogenic effects of liposomal prednisolone phosphate on B16 melanoma in mice. J Control Release 113: 1-8, 2006.

23. Del Rio D, Stewart AJ and Pellegrini N: A review of recent studies on malondialdehyde as toxic molecule and biological marker of oxidative stress. Nutr Metab Cardiovasc Dis 15: 316-328, 2005.

24. Karatas F, Karatepe M and Baysar A: Determination of free malondialdehyde in human serum by high-performance liquid chromatography. Anal Biochem 311: 76-79, 2002.

25. Culver C, Sundqvist A, Mudie S, Melvin A, Xirodimas D and Rocha S: Mechanism of hypoxia-induced NF-kappaB. Mol Cell Biol 30: 4901-4921, 2010.

26. Nakayama K: cAMP-response element-binding protein (CREB) and $\mathrm{NF}-\kappa \mathrm{B}$ transcription factors are activated during prolonged hypoxia and cooperatively regulate the induction of matrix metalloproteinase MMP1. J Biol Chem 288: 22584-22595, 2013.

27. Vaupel P, Mayer A and Höckel M: Tumor hypoxia and malignant progression. Methods Enzymol 381: 335-354, 2004.

28. Semenza GL: HIF-1, O(2) and the 3 PHDs: How animal cells signal hypoxia to the nucleus. Cell 107: 1-3, 2001.
29. Semenza GL: Defining the role of hypoxia-inducible factor 1 in cancer biology and therapeutics. Oncogene 29: 625-634, 2010.

30. Glynn SA, O'Sullivan D, Eustace AJ, Clynes $M$ and O'Donovan N: The 3-hydroxy-3-methylglutaryl-coenzyme A reductase inhibitors, simvastatin, lovastatin and mevastatin inhibit proliferation and invasion of melanoma cells. BMC cancer 8: 9, 2008.

31. Rius J, Guma M, Schachtrup C, Akassoglou K, Zinkernagel AS, Nizet V, Johnson RS, Haddad GG and Karin M: NF-kappaB links innate immunity to the hypoxic response through transcriptional regulation of HIF-1alpha. Nature 453: 807-811, 2008.

32. Krock BL, Skuli N and Simon MC: Hypoxia-induced angiogenesis: Good and evil. Genes Cancer 2: 1117-1133, 2011.

33. Kerbel RS: Tumor angiogenesis: Past, present and the near future. Carcinogenesis 21: 505-515, 2000.

34. Lieu C, Heymach J, Overman M, Tran H and Kopetz S: Beyond VEGF: Inhibition of the fibroblast growth factor pathway and antiangiogenesis. Clin Cancer Res 17: 6130-6139, 2011.

35. Calvani M, Rapisarda A, Uranchimeg B, Shoemaker RH and Melillo G: Hypoxic induction of an HIF-1alpha-dependent bFGF autocrine loop drives angiogenesis in human endothelial cells. Blood 107: 2705-2712, 2006.

36. Shirasuna K, Shimamura N, Seno K, Ohtsu A, Shiratsuki S, Ohkuchi A, Suzuki H, Matsubara S, Nagayama S, Iwata H and Kuwayama T: Moderate hypoxia down-regulates interleukin-6 secretion and TLR4 expression in human Sw.71 placental cells. Cell Physiol Biochem 36: 2149-2160, 2015.

37. Addison CL, Arenberg DA, Morris SB, Xue YY, Burdick MD, Mulligan MS, Iannettoni MD and Strieter RM: The CXC chemokine, monokine induced by interferon-gamma, inhibits non-small cell lung carcinoma tumor growth and metastasis. Hum Gene Ther 11: 247-261, 2000.

38. Samten B, Townsend JC, Weis SE, Bhoumik A, Klucar P, Shams H and Barnes PF: CREB, ATF and AP-1 transcription factors regulate IFN-gamma secretion by human $\mathrm{T}$ cells in response to mycobacterial antigen. J Immunol 181: 2056-2064, 2008.

39. Mann DA, Trim J, Smart D, Wright MC and Michael JP: Control of TIMP-1 gene transcription in hepatic myofibroblasts by a combination of AP-1 proteins and novel transcription factors. Int J Exp Pathol 81: A18-A19, 2000.

40. Bonello S, Zähringer C, BelAiba RS, Djordjevic T, Hess J, Michiels C, Kietzmann T and Görlach A: Reactive oxygen species activate the HIF-1alpha promoter via a functional NFkappaB site. Arterioscler Thromb Vasc Biol 27: 755-761, 2007.

41. Pialoux V, Mounier R, Brown AD, Steinback CD, Rawling JM and Poulin MJ: Relationship between oxidative stress and HIF-1 alpha mRNA during sustained hypoxia in humans. Free Radic Biol Med 46: 321-326, 2009.

42. Guterres FA, Martinez GR, Rocha ME and Winnischofer SM: Simvastatin rises reactive oxygen species levels and induces senescence in human melanoma cells by activation of p53/p21 pathway. Exp Cell Res 319: 2977-2988, 2013.

43. Qi XF, Kim DH, Yoon YS, Kim SK, Cai DQ, Teng YC, Shim KY and Lee KJ: Involvement of oxidative stress in simvastatin-induced apoptosis of murine CT26 colon carcinoma cells. Toxicol Lett 199: 277-287, 2010.

44. Licarete E, Sesarman A and Banciu M: Exploitation of pleiotropic actions of statins by using tumour-targeted delivery systems. J Microencapsul. 32: 619-631, 2015.

45. May MJ, D'Acquisto F, Madge LA, Glöckner J, Pober JS and Ghosh S: Selective inhibition of NF-kappaB activation by a peptide that blocks the interaction of NEMO with the IkappaB kinase complex. Science 289: 1550-1554, 2000.

46. Amiri KI, Horton LW, LaFleur BJ, Sosman JA and Richmond A: Augmenting chemosensitivity of malignant melanoma tumors via proteasome inhibition: Implication for bortezomib (VELCADE, PS-341) as a therapeutic agent for malignant melanoma. Cancer Res 64: 4912-4918, 2004 